\title{
Analysis of Primary School Fourth-grade Students' Social Studies Course Achievements, GPA and Motivations for Social Studies Course in Terms of Gender
}

\author{
Barış Çetin \\ Faculty of Education, Çanakkale Onsekiz Mart University, Turkey
}

Copyright@2019 by authors, all rights reserved. Authors agree that this article remains permanently open access under the terms of the Creative Commons Attribution License 4.0 International License

\begin{abstract}
In this study, primary school fourth-grade students' success in a social studies course, general academic success, and motivations towards the social studies course have been investigated as to explore whether differences exist from a gender perspective. A correlation survey method has been employed. Participants of the study include 504 girls and 476 boys for a total of 980 students from eleven public and two private schools located in Canakkale Provincial School District. Data has been gathered through the use of the "Social Studies Course Motivation Scale" developed by Tahiroğlu ve Aktepe (2017) and a "Personal Information Form". This study concluded that primary school fourth grade students' general motivation scores concerning social studies course success and associated sub-factors as "agree/ definitely agree" level. A significant relationship has been determined between primary school fourth grade students' GPA and social studies success, GPA and general motivation scores towards social studies course, success in social studies and general total scores of motivations towards social studies. While there has been a significant difference in general motivation scores towards of social studies course and GPA in favour of girls, no significant difference has been found in social studies success scores between male and female students.
\end{abstract}

Keywords Elementary Social Studies, Social Studies Motivation, Gender

\section{Introduction}

Motivation, interest, attitude, inducement, self-efficacy, self-belief and value take place within the affective domain. These, however, are the factors that influence learning.
Whether the motivation factor, which is an important element of the affective domain, is affected by the gender variable is discussed in this study.

In the literature, there are many different definitions of motivation. Some of these definitions are as follows: motivation, in general, means giving energy to behaviour. Motivation refers to continuity and tendency toward behaviour [1]. "Motivation is a need or desire that stimulates behaviour and directs it towards a goal" [2]. There are many different theories of motivation in the literature. One of these theories, the self-determination theory developed by [3], forms the foundation of the current study.

\subsection{Self-determination Theory (SDT)}

SDT bases personality development and human behaviour as experimentally on organism theory and mainly focuses on psychological level [4]. SDT indicates self-determination and the freedom of initiating a person's behaviour [3]. SDT is not only to understand the nature and consequences of autonomy but also considers how autonomy develops, and how specific, biological, and social conditions can be reduced or facilitated [5]. SDT divides motivation into three categories as intrinsic motivation, extrinsic motivation, and amotivation [3].

"Intrinsic motivation is the energy source, which is in the centre of active nature of the human organism" [3]. Intrinsic motivation is defined as carrying out an activity to ensure internal satisfaction [6]. Intrinsic motivation includes a process that individuals consider either a goal or an activity as interesting or useful and realize through their internal [7]. Intrinsic motivation has an association with academic performance [3]. Extrinsic motivation expresses the gaining of benefit from an activity itself rather than its instrumental value [8]. The individual with an extrinsic 
motivation is the person who acts in order to get the reward. If there is no reward, the behaviour will not occur [9]. One of the most proper examples of extrinsically motivated behaviours is what is done to obtain a concrete reward and to avoid punishment [10]. Amotivation explains a situation in which someone is not being motivated to act [4].

\subsection{Primary School Social Studies}

Barth \& Demirtaş [11] defines the social studies course as; "Citizenship Education Curriculum provides objectives that are appropriate to the duties of responsible citizens in Turkish democratic society and establishes its content in relation with history, geography, and citizenship knowledge, and provides lifelong citizenship skills." (p.6). According to Öztürk [12] social studies "is a curriculum for the purpose of educating active citizens to make decision and to solve problem by merging the knowledge and methodology gained from social sciences in a changing national and global conditions from all aspects". (p.24)

"An important part of knowledge, skills, and values is being taught to the students through a social studies course in primary schools"[13]. According to Deveci [14], the main purpose of the social studies course is students' socialization and ensuring that they become a good citizen. One of the competences that the student needs to gain in the 2018 social studies program is developing an ability to learn how to learn. "Learning how to learn is the ability of an individual to pursue and be persistent in learning process to organize his/ her own learning action as individually or a group, including effective time and knowledge management." [15]. In order for students to attain the stated objectives and competencies of the 2018 social studies program, they should present high motivation in learning the social studies course.

\subsection{The Impacts of Gender on Academic Achievement and Motivation}

In this part, the results of national and international research regarding the effect of gender on academic achievements and motivation of primary school students are provided.

Many studies have revealed that men have more competence in mathematics, science, and athletics than girls (Crain, 1996, cite by [16]; [17]. Peterson [18] presented that girls showed higher reading motivation and reading success than boys. Bozkurt [19], in terms of reading motivation and its sub-dimensions, female students have higher intrinsic and extrinsic motivations than males. Budak [20] found that mathematics motivation levels of the fourth-grade students in primary school did not differ according to the gender variable. Demir and Budak [21] found a moderate relationship between mathematics achievement and motivation. Anderson, Leyland \& Ling [22] found that girls were more motivated to participate in extracurricular dance activities than men. Chung \& Chang [23] found that female students' motivation was significantly higher than male students in moderate digital game.

In the USA, in the general population from primary school second grade to high school eleventh grade, it was determined that standardized tests results in math skills did not differ between male and female students [24]. Lindberg, Shibley Hyde \& Hirsch [25] found no difference in math scores between male and female students.

\subsection{Present Study}

The high motivation level of primary school students towards the social studies course will have a positive effect on the success of students and therefore, will make a significant contribution in selecting accurate professions in the following years.

In the fourth-grade social studies curriculum, students are expected to acquire cognitive and psychomotor goals as well as affective ones [15]. In addition, in 2018 social studies curriculum, the values of "justice, importance to family unity, independence, peace, scientific process, diligence, solidarity, sensitivity, honesty, aesthetics, equality, freedom, respect, love, responsibility, savings, patriotism, (and) charity" exist [15]. Values are a very important element of the affective field.

The most important factor that has an impact on learning of cognitive behavior is affective features. Affective features are inevitably important in developing students' perceptual skills [26]. In order for fourth grade students to be successful and achieve a GPA at an intended level, it is imperative that the cognitive, psychomotor skills and the affective skills develop together. In the literature, no relevant study has been found that investigated whether there is a difference in the social knowledge achievements of primary school fourth-grade students, their GPA's and the motivation towards the social studies course and its sub-factor scores in relation to gender. It is expected that the results of this study would contribute to the Ministry of National Education, classroom teachers, and researchers who conduct research in this field. The general purpose of this study is to determine whether there is a difference between the social studies achievements of primary school fourth-grade students, their GPAs, and motivation scores for the social studies course in terms of gender. Depending on this purpose, the research questions sought in this research are:

\subsection{Sub Objectives}

1. What are the levels of the total and sub-factor scores of the primary school fourth grade students' motivation for social studies course; levels in achievements of social studies, and GPA? 
2. Are there relations among social studies achievements of primary school fourth-grade students, the total score of motivation for the social studies course with GPAs, and sub-factor scores for "motivation to succeed" "motivation for goals" "motivation for interests, desires and needs", "amotivation" and "motivation appreciation?"

3. Are there differences among the total scores of the primary school fourth-grade students' motivation for social studies course; "motivation to succeed" "motivation for goals"; "motivation for interests, desires and needs", "amotivation" and "motivation sub-factor scores for appreciation; in relation to social studies achievements and GPAs differ gender?

\section{Methods}

Because this study investigates whether primary school fourth-grade students' total and sub-factor scores of motivations for social studies lessons, social studies course achievements and GPA levels differ in terms of gender; and the relationship between primary school fourth-grade students' total and sub-factor scores of motivations for social studies lessons, social studies course achievements and GPA levels, a correlational survey model was used.

\subsection{Participants}

Participant of this study include 504 girls and 476 boys, for a total of 980 participants, from eleven public and two private primary schools within Canakkale Province in the 2017-2018 academic year.

\subsection{Data Collection Instruments}

Social Studies Course Motivation Scale: This scale has been developed by [27] to determine the motivation level of fourth and fifth grade students. Construct validity of the scale has been determined with factorial analysis. According to factorial analysis, scale constructs include five sub-dimensions, 29 items, and 5-point Likert scale type. For reliability, a Cronbach's Alpha coefficient has been calculated. "Motivation towards success" 0.71, "motivation towards a goal" 0.66 , "motivation towards interest, demand, and needs" 0.70, "amotivation" 0.64, "motivation towards appreciation" 0.57 and overall Cronbach's Alpha of the scale has been calculated as 0.83 [27].

GPA and Social Studies Course Success: These are comprised of primary school 4th grade students' self-reported social studies course grades and GPAs. The distribution of students' GPAs and success in the social studies course has been presented in Table 1.
Table 1. Distribution of students' GPAs and success in social studies course [28]

\begin{tabular}{cccccc}
\hline & \multicolumn{3}{c}{$\begin{array}{c}\text { Social } \\
\text { Studies }\end{array}$} & \multicolumn{3}{c}{ GPA } \\
\hline Grade & Score & $\mathrm{f}$ & Valid \% & $\mathrm{f}$ & Valid \% \\
5 & $85-100$ & 589 & 86.5 & 638 & 86.9 \\
4 & $70-84$ & 68 & 10.0 & 78 & 10.6 \\
3 & $55-69$ & 18 & 2.6 & 15 & 2.0 \\
2 & $45-54$ & 6 & .9 & 2 & .3 \\
1 & $0-44$ & & & 1 & .1
\end{tabular}

Personal Information Form: This form consists of questions about gender, school type, GPA, and Social Studies Success.

\subsection{Data Collection and Analysis}

In order to conduct the study, official permission was obtained from Canakkale Governorship and Canakkale Provincial Directorate of National Education. Researcher gathered face to face data in the 2017-2018 academic year from eleven public and two private primary schools fourth grade students by using "Social Studies Course Motivation Scale" and "Personal İnformation Form."

One negative item in "Motivation for interests, desires and needs" and "5 negative items in "Amotivation" sub-dimensions were reversed. Data gathered via "Social Studies Course Motivation Scale" has been analysed by implementing SPSS 21.00 statistics program.

Normality analysis was conducted by using Shapiro-Wilk technique for primary school fourth grade students' general motivation and sub-factor scores, GPA, and social studies success [29]. The normality distributions of the data can be understood by observing the Kolmogorov-Smirnov $(30,31)$ and Shapiro Wilk tests [30]. Since primary school fourth grade students' general motivation and sub-factor scores, GPA, and social studies success did not demonstrate normal distribution, "Spearman's rank correlation test" and "Mann-Whitney Technique" have been used.

The Mann-Whitney U test is used instead of t-test for independent groups when there is no normality assumption [32]. Spearman rank correlation is used in situations when the distribution of variables is away from normality [33].

In order to assess primary school fourth grade students' general motivation and sub-factor scores, GPA, and social studies success, descriptive statistical analysis has been conducted. To determine if a relationship exists in the social studies success concerning GPA with motivation towards social studies course, a nonparametric "Spearman's Rank Correlation" technique was used. Also, to identify whether the relations differ in social studies success and GPA with regard to gender towards social studies course, a nonparametric "Mann-Whitney" technique was employed. 
Table 2. Alternatives and point differentials in Primary School fourth graders' social studies course motivation scale

\begin{tabular}{lcc}
\hline Alternatives & Points & Point Differentials \\
\hline Definitely Agree & 5 & $4,20-5,00$ \\
Agree & 4 & $3,40-4,19$ \\
Undecided & 3 & $2,60-3,39$ \\
Disagree & 2 & $1,80-2,59$ \\
Definitely Disagree & 1 & $1,00-1,79$ \\
\hline
\end{tabular}

\section{Result}

Findings are presented concerning the relationship of primary school fourth-grade students' levels of motivation towards the social studies course, success in social studies, and GPAs in Canakkale Central Province. Also, the relationship between fourth grade students' total and sub-dimensions score of motivation, achievement in social studies course, and GPA are presented. In addition, findings whether fourth grade students' total and sub-dimensions scores of motivation, achievement in the social studies course, and GPA level differences in relation to gender are addressed.

\subsection{Findings Related with the Relationship of Primary School Fourth-grade Students' Levels of Total Scores of Motivation and Sub-factors Scores, Social Studies Course Success and GPA in Social Studies, and GPAs}

Table 3. Findings related with the relationship of primary school fourth-grade students' levels of total scores of motivation and sub-factors scores, social studies course success and GPA in social studies course, and GPA levels

\begin{tabular}{lccc}
\hline Variables & $\mathrm{N}$ & $\bar{x}$ & $\mathrm{~S}$ \\
\hline GPA & 734 & 4.8392 & .45692 \\
Social Studies Success & 681 & 4.8209 & .50314 \\
Motivation Towards Success & 980 & 4.3724 & .69339 \\
Motivations Towards Aims & 980 & 4.3710 & .80315 \\
Motivation towards interest, demand & 980 & 4.0425 & .68429 \\
and need & 980 & 3.8335 & 1.30830 \\
Amotivation & 980 & 4.0182 & 1.16198 \\
Motivation towards appreciation & 980 & 4.1622 & .58750 \\
Total in general & & & \\
\hline
\end{tabular}

According to table 3, a mean score of motivation of primary fourth grade students towards social studies course was determined as $\bar{x}=4.1622$. As sub-dimensions were evaluated, the least proficient factor was "amotivation $(\bar{x}$ $=3.8335)$ " while the most proficient sub-factor was "Motivation towards success $(\bar{x}=4.3724) . "$ When maximum and minimum points were considered, it was determined that primary school fourth grade students' motivation towards the social studies course was considerably high. In addition, results showed that primary school fourth grade students' GPAs ( $\bar{x}=4.8392)$ were related to success in the social studies course $(\bar{x}=4.8209)$. These results demonstrate that the relationship between primary school fourth grade students' success in social studies and their GPAs are significantly high.

\subsection{Findings Related to Social Studies Success, GPAs and Motivation towards Social Studies Total and Sub-factor points}

According to Table 4 there is a positive meaningful relationship between primary school fourth grade students' GPAs and social studies success [r=.621; $<<0.01]$; and there has been a positive meaningful relationship between primary school fourth grade students' GPA and total score of motivation towards social studies [r=.201; $\mathrm{p}<0.01]$. It has been found that there is a positive meaningful relationship among primary school fourth grade students' Social studies success and "Motivation Towards Success" $[\mathrm{r}=.201 ; \mathrm{p}<0.01]$, "Motivations Towards Aims" $[\mathrm{r}=.102$; $\mathrm{p}<0.01]$, "amotivation" $[\mathrm{r}=.102 ; \mathrm{p}<0.01]$, "Motivation towards interest, demand and need" $[\mathrm{r}=.087 ; \mathrm{p}<0.05]$, sub-factor scores and motivation total scores towards social studies course [r=.149; $p<0.01]$. In relation to primary school fourth grade students' GPAs and social studies success, it was found that there is no relationship concerning primary school fourth graders' social studies success and "Motivation towards appreciation" $[\mathrm{r}=.037$; $\mathrm{p}>0.05]$.

\subsection{Finding of Primary School Fourth-grade Students' Motivation for Social Studies Course and Sub-dimension Points; Social Studies Success and GPA Differences according to Gender}

According to table 5, there is no significant difference between primary school fourth-grade students' social studies success scores $(U=57776.000 ; p>.05)$ and primary school fourth-grade students' motivation scores for appreciation $\left(U=117735.500 ; p^{>} .05\right)$ in relation to gender.

Results did indicate a significant difference in favour of girls concerning the sub-dimensions of "motivation to succeed" ( $\mathrm{U}=99222.000 ; \mathrm{p}<.01)$; "motivation for goals" $(\mathrm{U}=101666.500 ; \mathrm{p}<.01)$; "motivation for interests, desires and needs" $(\mathrm{U}=103595.000 ; \mathrm{p}<.01)$; "amotivation" $(\mathrm{U}=104537.500 ; \mathrm{p}<.01)$; total score of motivation towards social studies course $(\mathrm{U}=102601.000 ; \mathrm{p}<.01)$; primary school fourth-grade students' GPAs ( $U=63503.000$; $p$ $<.05)$. 
Table 4. Results of correlational analysis related to social studies success, GPAs and motivation towards social studies with respect to total and sub-factor points

\begin{tabular}{|c|c|c|c|c|c|c|c|c|}
\hline Variables & GPA & $\begin{array}{c}\text { Social } \\
\text { studies } \\
\text { success }\end{array}$ & $\begin{array}{c}\text { Motivation } \\
\text { Towards } \\
\text { Success }\end{array}$ & $\begin{array}{c}\text { Motivations } \\
\text { Towards } \\
\text { Aims }\end{array}$ & $\begin{array}{c}\text { Motivation } \\
\text { towards } \\
\text { interest, } \\
\text { demand and } \\
\text { need } \\
\end{array}$ & Amotivtaion & $\begin{array}{l}\text { Motivation } \\
\text { towards } \\
\text { appreciation }\end{array}$ & $\begin{array}{c}\text { General } \\
\text { total }\end{array}$ \\
\hline GPA & 1.000 & $.621^{* *}$ & $.252^{* *}$ & $.117^{* *}$ & $.087^{*}$ & $.157^{* *}$ & .045 & $.201^{* *}$ \\
\hline Social studies success & $.621^{* *}$ & 1.000 & $.201^{* *}$ & $.102^{* *}$ & $.087^{*}$ & $.102^{* *}$ & .037 & $.149^{* *}$ \\
\hline Motivation Towards Success & $.252^{* *}$ & $.201^{* *}$ & 1.000 & $.636^{* *}$ & $.518^{* *}$ & $.129^{* *}$ & $.382^{* *}$ & $.660^{* *}$ \\
\hline Motivations Towards Aims & $.117^{* *}$ & $.102^{* *}$ & $.636^{* *}$ & 1.000 & $.598^{* *}$ & $.089^{* *}$ & $.468^{* *}$ & $.673^{* *}$ \\
\hline $\begin{array}{l}\text { Motivation towards interest, } \\
\text { demand and need }\end{array}$ & $.087^{*}$ & $.087^{*}$ & $.518^{* *}$ & $.598^{*}$ & 1.000 & $.297^{* *}$ & $.409^{* *}$ & $.740^{* *}$ \\
\hline Amotivation & $.157^{* *}$ & $.102^{* *}$ & $.129^{* *}$ & $.089^{* *}$ & $.297^{* *}$ & 1.000 & -.054 & $.571^{* *}$ \\
\hline $\begin{array}{l}\text { Motivation towards } \\
\text { appreciation }\end{array}$ & .045 & .037 & $.382^{* *}$ & $.468^{* *}$ & $.409^{* *}$ & -.054 & 1.000 & $.586^{* *}$ \\
\hline General Total & $.201^{* *}$ & $.149^{* *}$ & $.660^{* *}$ & $.673^{* *}$ & $.740^{* *}$ & $.571^{* *}$ & $.586^{* *}$ & 1.000 \\
\hline
\end{tabular}

**. Correlation is significant at the 0.01 level (2-tailed).

*. Correlation is significant at the 0.05 level (2-tailed).

Table 5. Finding of primary school fourth-grade students' motivation for social studies course and sub-dimension points; social studies success and GPA differences according to gender

\begin{tabular}{|c|c|c|c|c|c|c|}
\hline Variables & Gender & $\mathrm{N}$ & Mean Rank & Sum of Ranks & $\mathrm{U}$ & $\mathrm{p}$ \\
\hline & Girl & 377 & 377.56 & 142339.00 & & \\
\hline \multirow[t]{3}{*}{ GPA } & Boy & 357 & 356.88 & 127406.00 & 63503.000 & .024 \\
\hline & Total & 734 & & & & \\
\hline & Girl & 352 & 340.64 & 119904.00 & & \\
\hline \multirow[t]{3}{*}{ Social Studies Success } & Boy & 329 & 341.39 & 112317.00 & 57776.000 & .933 \\
\hline & Total & 681 & & & & \\
\hline & Girl & 504 & 531.63 & 267942.00 & & \\
\hline \multirow[t]{3}{*}{ Motivation to succeed } & Boy & 476 & 446.95 & 212748.00 & 99222.000 & .000 \\
\hline & Total & 980 & & & & \\
\hline & Girl & 504 & 526.78 & 265497.50 & & \\
\hline \multirow[t]{3}{*}{ Motivation for goals } & Boy & 476 & 452.09 & 215192.50 & 101666.500 & .000 \\
\hline & Total & 980 & & & & \\
\hline & Girl & 504 & 522.95 & 263569.00 & & \\
\hline \multirow[t]{3}{*}{ Motivation for interests, desires and needs } & Boy & 476 & 456.14 & 217121.00 & 103595.000 & .000 \\
\hline & Total & 980 & & & & \\
\hline & Girl & 504 & 521.08 & 262626.50 & & \\
\hline \multirow[t]{3}{*}{ Amotivation } & Boy & 476 & 458.12 & 218063.50 & 104537.500 & .000 \\
\hline & Total & 980 & & & & \\
\hline & Girl & 504 & 486.10 & 244995.50 & & \\
\hline \multirow[t]{3}{*}{ Motivation for appreciation } & Boy & 476 & 495.16 & 235694.50 & 117735.500 & .608 \\
\hline & Total & 980 & & & & \\
\hline & Girl & 504 & 524.93 & 264563.00 & & \\
\hline \multirow[t]{2}{*}{ General Total } & Boy & 476 & 454.05 & 216127.00 & 102601.000 & .000 \\
\hline & Total & 980 & & & & \\
\hline
\end{tabular}




\section{Discussion, Conclusions and Suggestions}

This study investigated whether primary school fourth-grade students' total and sub-dimension scores of motivation, achievement in social studies course, and GPA level differ in relation to gender and analysed any relationship among primary school fourth-grade students' total and sub-dimension scores of motivation, achievement in social studies course and GPA level.

Primary school fourth grade students' general motivation scores concerning the social studies course success and sub-factors showed at an "agree and definitely agree" level. In literature, no studies have been encountered that supports the results of this present study. The results of this study demonstrate that primary school fourth grade students' general motivation scores concerning social studies course success and sub-factors are well and social studies success and GPA are at a very good level.

It has been found that there is a significant positive relationship between primary school fourth grade students' GPAs, social studies success, GPAs and motivation towards the social studies course. It has also been found that there has been a positive meaningful relationship among Social studies success and "Motivation Towards Success" "Motivations Towards Aims", "amotivation", "Motivation towards interest, demand and need" among sub-dimension point and general motivation about social studies course. In relation to primary school fourth grade students' GPAs and social studies success. However, no significant relationship between primary school fourth graders' social studies success and "Motivation towards appreciation" was found.

There are studies that show similarities with this study: Gottfried [34] determined a positive relationship between general academic intrinsic motivation and success. Lemos \& Veríssimo [35] indicated a positive relationship between general academic intrinsic motivation and success and a negative relationship between extrinsic motivation and success among fourth grade students. Othman \& Leng [36] identified a low correlation between intrinsic motivation and success. Gerstner [37] found low nonsignificant relationship between intrinsic motivation and success. Gottfried [38] ascertained a negative correlation between intrinsic motivation and social studies course success. Gottfried [39], determined a positive relationship between general academic intrinsic motivation and social studies course success.

It can be concluded that the current results gathered demonstrate that primary school fourth grade students' motivation levels have a positive impact on students' GPAs. Furthermore, "Motivation Towards Success", "Motivations Towards Aims", "amotivation", "Motivation towards interest, demand and need" sub-dimensions and general motivation total scores concerning the social studies course have effected social studies success positively. It has rendered a relationship between children who want to receive higher score on the social studies course and motivation towards social studies course. In contrast with these results, motivation towards appreciation sub-factor did not improve social studies success meaningfully.

It has been found that there is a significant positive relationship between primary school fourth grade students' GPAs and social studies success as well as GPAs and motivation towards the social studies course. It has also been found that there have been positive meaningful relationships among Social studies success and "Motivation Towards Success" "Motivations Towards Aims", "amotivation" in favour of girls. The results of this study show that, Social studies success and "Motivation Towards Success" "Motivations Towards Aims", "amotivation", "Motivation towards interest, demand and need" sub-dimension have been effected by the gender variable. The study, which did not show similarity with the results of this study, Gerstner (37) did not find a significant difference between boy and girl students' internal motivations towards social studies course.

From the results of this study, it can be concluded that female students' GPAs and motivation levels towards the social studies course are higher than male students. The reason for female students' holding higher GPAs may be because they are more organized in studying, more careful listeners, and more willing to complete homework than male students.

Significant relationship between female and male students has not been determined in relation to Primary school fourth grade students' social studies success and "Motivation towards appreciation." This result show that primary school fourth grade students' social studies success and "Motivation towards appreciation" sub-dimension is similar and has not been affected by gender factor.

A study should be conducted using different sampling with respect to whether primary school fourth grade students' social studies success and "Motivation towards appreciation" differ according to gender.

Students could be informed and provided with extra lessons for level differences for the purpose of eliminating differences in sub-factors in "Motivation Towards Success" "Motivations Towards Aims", "amotivation" "Motivation Towards Success" "Motivations Towards Aims", "amotivation", "Motivation towards interest, demand and need", and GPAs.

\section{REFERENCES}

[1] Hebb, D. O. (1955). Drives and the CNS (conceptual nervous system). Psychological Review, 62, 243-254. 
Retrieved from https://web-b-ebscohost-com.proxy.lib.sfu. ca/ehost/pdfviewer/pdfviewer?vid=1\&sid=faaf7a5f-8b13-4 a71-9ef0-4c870fe 5e 46c\% 40 pdc-v-sessmgr01

[2] Myers, D. G. (2010). Psychology. Ninth edition. New York: Worth publishers.

[3] Deci, E. L., \& Ryan, R. M. (1985). Intrinsic motivation and self- determination in human behavior. New York: Plenum Press.

[4] Ryan, R.M., \& Deci, E. (2017). Self-determination Theory basic psychological needs in motivation, development, and wellness. New York London: The Guilford Press.

[5] Ryan, R. M., \& Deci, E. L. (2006). Self-Regulation and the problem of human autonomy: Does psychology need choice, self-determination, and will? Journal of Personality, 74, $1557-1585$.

[6] Ryan, R. M., \& Deci, E. L. (2000a). Self-determination theory and the facilitation of intrinsic motivation, social development, and well- being. American Psychologist, 55 1), 68-78.

[7] Koestner, R., Losier, G.F. (2002). Distinguishing three ways of being internally motivated: A Closer look at introjection, identification and intrinsic motivation. In Deci, E. L., \& Ryan, R. M. (Eds.), Handbook of self-determination research. Rochester (pp.101-122). Rochester, NY: University of Rochester Press.

[8] Ryan, R.M. \& Deci, E.L. (2000b). Intrinsic and extrinsic motivations: Classic definitions and new directions. Contemporary Educational Psychology, 25, 54-67. doi:10.1006/ceps.1999.1020

[9] Deci E. (1975). Intrinsic motivation. New York: Plenum Press.

[10] Deci, E.L. \& Ryan, R.M. (2008). Facilitating optimal motivation and psychological well- being across life's domains. Canadian Psychology, 49 (1), 14-23.

[11] Barth, J. L., \& Demirtaş, A. (1997). İlköğretim sosyal bilgiler öğretimi. Ankara: Yükseköğretim Kurulu Milli Eğitim Geliştirme Projesi Hizmet Öncesi Öğretmen Eğitimi.

[12] Öztürk, C. (2006). Sosyal bilgiler: Toplumsal yaşama disiplinlerarası bir bakış. In C. Özturk, C. (Ed.), Hayat bilgisi ve Sosyal Bilgiler öğretimi Yapılandırmacı Bir Yaklaşım (pp.21-50). Ankara: Pegem A Yayıncılık.

[13] Kılıçoğlu, G. (2012). Sosyal bilgiler tanımı, dünyada ve ülkemizde gelişimi ve önemi. In M. Safran (Ed.), Sosyal bilgiler öğretimi (pp. 3-016). Ankara: Pegem Akademi.

[14] Deveci, H. (2003). Sosyal Bilgiler dersinde probleme dayalı öğrenmenin öğrencilerin derse ilişsin tutumlarına, akademik başarılarına ve hatırlama düzeylerine etkisi (Unpublished doctoral dissertation). Anadolu Üniversitesi, Eskişehir.

[15] Milli Eğitim Bakanlığı (MEB, 2018). Sosyal bilgiler dersi öğretim Programı (İlkokul ve Ortaokul 4, 5, 6 ve 7 sınıflar) Retrieved from http://mufredat.meb.gov.tr/Dosyalar/20181 2103847686-SOSYAL\%20BILLGILER\%20ÖĞRETIM\%2 0PROGRAMI\%20.pdf

[16] Carreira, J.M. (2011). Relationship between motivation for learning EFL and intrinsic motivation for learning in general among Japanese elementary school students, System, 39, 90-102. Retrieved from

https://www.sciencedirect.com/science/article/pii/S034625 1X11000108

[17] Fredricks, J. A., Eccles, J. S., 2002. Children's competence and value beliefs from childhood through adolescence: growth trajectories in two male- sex-typed domains. Developmental Psychology 38 (4), 519- 533. DOI: 10.1037//0012-1649.38.4.519

[18] Peterson, E.S. (2015). Investigating the relationship between elementary students' motivation to read and academic achievement in reading (Unpublished Dissertation). University of North Dakota, United State of America.

[19] Bozkurt, M. (2013). Beşinci sınıf öğrencilerinin üstbilişsel okuduğunu anlama farkındalığı ve okuma motivasyonları ile okuma düzeyleri arasındaki ilișki, (Unpublished master's thesis). Bülent Ecevit Üniversitesi, Zonguldak.

[20] Budak, H. (2016). İlkokul dördüncü sınıf öğrencilerinin öz düzenleme, motivasyon, biliş üstü becerileri matematik dersi başarılarının belirlenmesi (Unpublished master's thesis). Çanakkale OnsekizMart Üniversitesi, Türkiye.

[21] Demir, M.K. \& Budak, H. (2016). İlkokul dördüncü sınıf öğrencilerinin oz düzenleme motivasyon biliş ustü becerileri ile matematik dersi başarılarının arasındaki ilişki, Buca Eğitim Fakültesi Dergisi, 41, 30-41.

[22] Anderson, S.D., Leyland, S.D., \& Ling, J. (2017). Gender differences in motivation for participation in extra-curricular dance: application of the Theory of Planned Behaviour. Research in Dance Education, 18 (2), 150-160. doi.org/10.1080/14647893.2017.1330325

[23] Chung, L.Y., \& Chang. R.C. (2016). The Effect of gender on motivation and student achievement in digital game-based learning: A Case study of a contented-based classroom. EURASIA Journal of Mathematics Science and Technology Education, 13(6), 2309-2327. doi 10.12973/eurasia.2017.01227a

[24] Hyde, J. S., Lindberg, S. M., Linn, M. C., Ellis, A., \& Williams, C. (2008). Gender similarities characterize math performance. Science, 321, 494-495. Retrieved from http://itp.wceruw.org/hyde\%20science\%2008.pdf

[25] Lindberg, S.M., \& Shibley Hyde, J., Hirsch, L.M. (2008). Gender and Mother-Child Interactions during Mathematics Homework: The Importance of Individual Differences. Merrill-Palmer Quarterly, 54 (2), 232-255. Retrieved from https://www.jstor.org/stable/pdf/23096285.pdf

[26] Duman, B., \& Yakar, A. (2017). Öğretime yönelik duyuşsal farkındalık ölçeği. Cumhuriyet International Journal of Education. 6 (1), 200-229. Retrieved from http://dergipark.gov.tr/download/article-file/314401

[27] Tahiroğlu, M. \& Aktepe, V. (2017). 4. ve 5. sınıf sosyal bilgiler dersi motivasyon ölçeği formunun geçerlilik ve güvenirlilik çalışması. International Periodical for the Languages, Literature and History of Turkish or Turkic, 10(3), 907-932. Retrieved from doi http://dx.doi.org/10.7827/TurkishStudies.7944

[28] Resmi Gazete. April 23, 2019 Retrieved from http://www.resmigazete.gov.tr/eskiler/2007/08/20070820- 
1.htm

[29] Can, A. (2013). SPSS ile bilimsel arastırma sürecinde veri analizi. Ankara. Pegem Akademi.

[30] Pituch, K.A. \& Stevens, J.P. (2016). Applied multivariate statistics for the social science analyses with SAS and IBM's SPSS. Sixth edition. New York and London. Routledge Taylor \& Francis Group.

[31] Mertler, C.A. \& Reinhart, R.V. (2017). Advanced and multivariate statistical methods practical application and interpretation. New York and London. Routledge Taylor \& Francis Group.

[32] Ho, R. (2014). Handbook of univariate and multivariate data analysis with IBM SPSS. Second Edition. Taylor \& Francis Group. Boca Raton, London, New York: Taylor \& Francis Group. Boca Raton, London, New York.

[33] Sungur, O. (Tarihsiz). SPSS uygulamalı çok değişkenli istatistik teknikleri. İçinde Kalaycı, Ş.(Ed.). 9 Bask1. Ankara. Dinamik akademi.

[34] Gottfried, A. E. (1990). Academic intrinsic motivation in young elementary school children. Journal of Educational Psychology, 82(3), 525-538. Retrieved from https://web-a-ebscohost-com.proxy.lib.sfu.ca/ehost/pdfvie wer/pdfviewer?vid=1\&sid=813a4af3-acb1-448f-916e-9d6 c9780e600\%40sdc-v-sessmgr01

[35] Lemos, M.S. \& Veríssimo, L. (2014). The relationships between intrinsic motivation, extrinsic motivation, and achievement, along elementary school. Social and Behavioral Sciences 112, 930. Retrieved fromhttps://ac.els-cdn.com/S1877042814012683/1-s2.0-S1 877042814012683-main.pdf? tid=ab16a41a-4fd5-42c2-8f 73-63fca51ab2c4\&acdnat $=1539539224 \_50316 \mathrm{bc} 3 \mathrm{fd} 24048$ 3 ca4346039b23242d

[36] Othman, N. \& Leng, K.B. (2011). The relationship between self-concept, intrinsic motivation, self- determination and academic achievement among Chinese primary school students. International Journal of Psychological Studies, 3 (1), 90-98. DOI:10.5539/ijps.v3n1p90

[37] Gerstner, G.M. (2017). Motivation of developing intrinsic motivation in elementary school students in grades four through six (Unpublished Dissertation). Concordia University Irvine, United State of America.

[38] Gottfried, A. E. (1982). Relationships between academic intrinsic motivation and anxiety in children and young adolescents. Journal of School Psychology, 20 (3), 205-215. Retrieved from https://ac-els-cdn-com.proxy.lib.sfu.ca/002 2440582900504/1-s2.0-0022440582900504-main.pdf? tid $=$ fedb37da-4138-4029-a463-468f0177a360\&acdnat $=1 \overline{53} 9$ 538423 85526c3eab9ebb49861a95e0f8c85d06

[39] Gottfried, A. E. (1985). Academic intrinsic motivation in elementary and junior high school students. Journal of Educational Psychology, 77(6), 631-645. Retrieved fromhttps://web-a-ebscohost-com.proxy.lib.sfu.ca/ehost/pd fviewer/pdfviewer?vid=1\&sid=582b4162-bc6a-41 cd-82d3 -42642 cdecf $4 \mathrm{c} \% 40$ sdc-v-sessmgr01 